\title{
Industry Productivity Growth: A Network Perspective
}

\author{
Joe Teng, Dazhong Wu, Fran Smith \\ Troy University, United States
}

\begin{abstract}
Background: This study investigates the determinants of industrial productivity growth from a network perspective. Objectives: The research focuses on the influence on a focal industry's productivity growth by its partner industries' productivity growth, and the impact of the focal industry's position in the supply chain network. Method/Approach: The paper models the economy as a customer-supplier industry network and empirically investigates how a focal industry's multifactor productivity is influenced by the productivities of industries that are connected to it, and how this influence is moderated by its position in the network. Results: Based on a balanced panel dataset of 55 industries from the United States Bureau of Economic Analysis (BEA) input-output accounts, the results indicate that a focal industry's productivity growth is positively associated with its partner industries' productivity growth, and that industries with higher centrality in the network tend to have higher productivity growth. Conclusions: The study concludes with a discussion on the implications of the findings and the contribution to the productivity literature. Several directions for further research were identified.
\end{abstract}

Keywords: industry network, multi-productivity, network centrality, network perspective, customer-supplier industry network

JEL classification: M21

Paper type: Research article

Received: Aug 11, 2015

Accepted: Sep 13, 2015

Citation: Teng, J., Wu, D., Smith, F. (2015), "Industry Productivity Growth: A Network Perspective", Business Systems Research, Vol. 6, No. 1, pp. 41-51.

DOI: 10.1515/bsrj-2015-0010

\section{Introduction}

Many studies have attributed productivity growth to technology innovations (Griffith et el., 2001; Wakelin, 2001; Huergo, Jaumandreu (2004)). For example, Doraszelski and Jaumandreu (2013) provide evidence that technology innovation (R\&D) plays a key role in determining the difference in productivities among firms. The literature also emphasizes the impact of technology spillovers on productivity. Technology/knowledge spillovers occur when firms imitate the technology innovators or learn good practices from other firms. According to the literature, innovations and 
imitations both play an important role in productivity improvement at the firm and industry levels.

In fact, a large body of studies have devoted to the role of technology spillovers in determining productivity growth. For example, Jaffe (1986) and Jaffe (1988) found that a firm's technology innovations have a positive impact on other firms' productivity growth if they all use similar technologies in their productions. On the other hand, different firms may benefit from technology spillovers at different levels, conditional on their own investment in technology innovations as the effects of imitation depend on their absorptive capabilities (Fung, 2005).

This paper looks at the determinants of industrial productivity growth from a network perspective. We model the economy as a network of supplier and customer industries, and study how this supplier-customer network affects a focal industry's productivity growth. Our approach is related to Ahern and Harford (2014) that use the approach to study merger activities. Using the network topology, we investigate two questions regarding the determinants of industrial productivity growth. The questions addressed are: (1) how does partner industries' productivity growth influence the focal industry's productivity growth? And (2) what is the impact of an industry's centrality in the supply chain network on its productivity growth?

We found that the productivity growth of a focal industry is positively associated with that of its partner industries. The extant literature indicates that supply chain partners may collaborate, coordinate, and intentionally invest in innovation activities through R\&D alliances, which benefit both sides (Rai et al., 2006, Zailani, Rajagopal, 2005, Cao, Zhang, 2011). They also learn from their trading partners how to improve their productivities. The diffusion of such positive externalities allows the productivity growth to propagate through the industrial network.

Our results also indicate that a focal industry's position in the network influences its productivity growth. More specifically, industries in more central positions tend to experience a higher productivity growth. Based on network theory, an industry is in a central position if it has a large number of inter-industry trading connections. Trading with a greater number of industries allows the focal industry to access a larger pool of knowledge from its trading partners, thereby increasing the opportunities that the focal industry may absorb best practices from its partners.

Apart from the economics literature that investigates the relationship between productivity growth and technology spillovers, this paper is also related to a growing literature in the business fields studying firm activities using the network approach (Ahern, 2012, Ahern, Harford, 2014, Aoibda, et al., 2014, Tsai, 2001). Furthermore, extant research indicates that network structure and degree centrality can impact firm level growth (Powell et al., 1996) and innovation (Ahuja, 2000). For example, based on a survey of units from two companies, Tsai (2001) found that more central firms have better business performance. Our research is different from Tsai (2001) in that we study the determinants of industry productivity using data that cover all of the 3-digit NAICS industries between 1997 and 2012 from the US government agencies.

Our research contributes to the literature as it uncovers the important role of industry network in productivity growth. A primary innovation of this paper is to model industry productivity growth using a network framework based on trade flows among industries. This network framework provides key benefits to the productivity literature as it allows researchers to use well-developed models based on network and graph theories to analyze productivity growth in a much more realistic environment.

The research is organized as follows. Section 2 discusses the data and the variables, and section 3 is devoted to the description of the model and the empirical 
analysis. Section 4 provides some concluding remarks, its contribution to the field, limitations of the study and suggestions for further research.

\section{Methodology}

\section{Construction of the Inter-industry Network}

We first obtained the annual USE matrix from 1997 to 2012 from the United States Bureau of Economic Analysis (BEA) input-output accounts. BEA provides annual Input-Output data at two levels, the 15-industry level and the 71-industry level. To be consistent with data from other sources we used the 71-industry level. Among the 71 industries, 5 are government agencies and was eliminated from the dataset. Therefore, a total of 66 industries are used for this study. The USE matrix provides information about the amount of commodities used by industries as inputs. Based on the USE matrix, we constructed an inter-industry network for each year between 1997 and 2012.

In the network, each vertex corresponds to an industry. If industry A's products are used as inputs by industry $B$, then an edge is drawn between industry $A$ and industry $B$ to show the trading relationship. Each edge is weighted based on how the two industries depend on each other. More specifically, following Aoibda, et al. (2014) we calculate the weight of the edge between industries $i$ and $j$ as

$A_{i j}=\frac{1}{4}\left(\frac{U_{i j}}{\sum_{k} U_{i k}}+\frac{U_{i j}}{\sum_{k} U_{k j}}+\frac{U_{j i}}{\sum_{k} U_{j k}}+\frac{U_{j i}}{\sum_{k} U_{k i}}\right)$

In the equation above, $U_{i j}$ is the amount of industry i's products (in terms of dollar value) consumed by industry $j$. The first ratio $\left(U_{i j} / \sum_{k} U_{i k}\right)$ is the sales from industry $i$ to industry $j$ as a proportion of industry i's total sales. This measures how important industry $j$ is as a customer to industry $i$. The second ratio $\left(U_{i j} / \sum_{k} U_{k j}\right)$ is the sales from industry $i$ to industry $j$ as a proportion of industry j's total purchases. This measures how important industry $i$ is as a supplier to industry $j$. Similarly, the third and fourth ratios measure how important industry $i$ is as a customer to industry $j$, and how important industry $j$ is as a supplier to industry $i$ respectively. Finally the average of the four ratios is the weight of the edge, which reflects the extent to which industry $i$ and industry $j$ rely on the edge (trade flow) between the two industries.

Figure 1 presents a plot of the inter-industry network based on the 2005 USE matrix. Each industry is represented as a vertex and labeled with its ID in the figure. For better visualization the width of each edge represents its weight. In other words, a thick/strong edge (e.g., the edge connecting industry 27, Retail Trade, and industry 7. Construction) is associated with a strong trading connection. The entire network consist of 1706 edges thus rendering it indecipherable. For better illustration, edges with weights less than 0.03 were filtered out and as a result only 217 edges are depicted in the figure. However, the model is based on the entire network with 1706 edges.

In Figure 1, industries that have more connections and/or strong connections with other industries are located at the center of the network based on their centrality ranking (Aoibda, et al., 2014, Newman, 2003). Examples of industries with high centrality are: Real Estate (44), Construction (7), Miscellaneous Professional, Scientific, and Technical Services (48), Wholesale Trade (26), Administrative and Support Services (50), Management of Companies and Enterprises (49), and Retail Trade (27). In the figure these industries' IDs are indicated in solid circles.

On the other hand, industries with few and/or weak connections with other industries are placed on the edge of the network. Examples of industries with low centrality include: Apparel and Leather and Applied Products (20), Social Assistance 
(55), Forestry, Fishing, and Related Activities (5), Textile Mills and Textile Product Mills (19), Motion Picture and Sounds Recording Industries (37), and Support Activities for Mining (5). These industries' IDs are indicated in dashed circles.

Figure 1

Inter-Industry Network Based On BEA Input-Output Table 2002

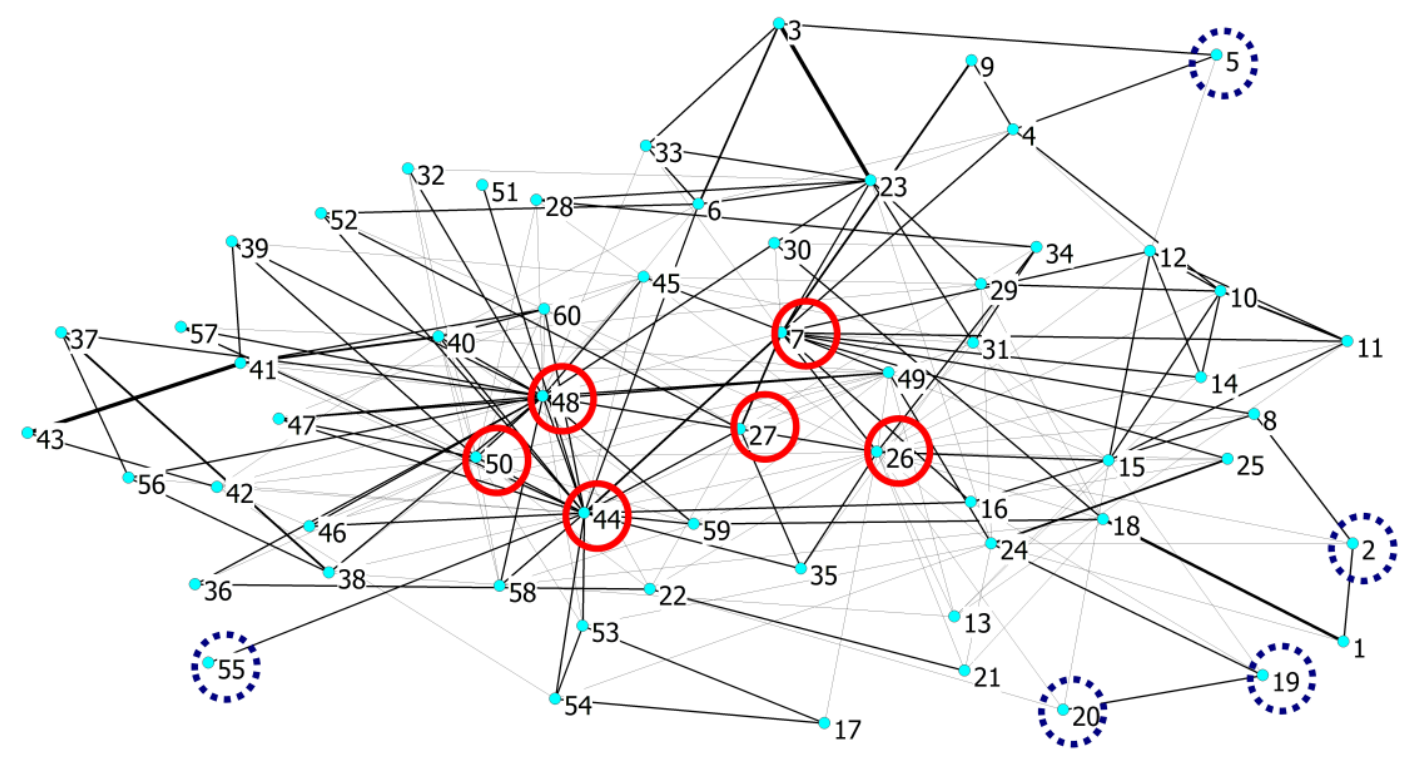

Source: author's illustration

\section{Variables}

Our dependent variable is productivity growth. The United States Bureau of Labor Statistics (BLS) provides the productivity growth data for industries at the summary level. There are 60 industries in the dataset, similar to the 3-digit NAICS (North America Industry Classification System) codes. Data are available at http://www.bls.gov/mfp/mprdload.htm. For each industry in each year, BLS provides its productivity level relative to its 2009 productivity level. For example, if an industry's productivity measure is 1.5 in year 2012, it indicates that its productivity increased by $50 \%$ from 2009 to 2012. Therefore, this variable measures productivity growth instead of productivity. For ease of explanation, we transformed the data so that the base year is 1997, the starting year of our entire dataset, rather than 2009. We restrict our data to post 1997 as BEA do not provide annual NAICS-based Input-Output data prior to 1997. It is to be noted that this transformation does not change our regression results.

Our independent variables include partner productivity growth, centrality, and research and development. For a focal industry $i$ in year $t$, its partner productivity growth $Z_{i t}$ is the weighted average of its partner industries' (i.e., industries that are directly connected to industry $i$ in the network) productivity growths:

$Z_{i t}=\sum_{j \neq i} \frac{A_{i j}}{A_{i *}} Y_{j t}$

where $A_{i j}$ is defined in Equation (1), $Y_{j t}$ is the productivity growth of industry $j$ in year $t$, and $A_{i *}$ is the sum of industry i's edges: 
$A_{i *}=\sum_{j \neq i} A_{i j}$

For example, suppose industry $i$ has two partner industries. Let the two industries be $A$ and $B$. The weights of the edges from industry $i$ to the two industries are 0.3 and 0.5 respectively. Suppose the productivity growth of industry $A$ is 0.2 and that of industry $B$ is 0.1 , then industry i's partner productivity growth is $\frac{0.3000}{0.3000+0.5000} \times 0.2000+$ $\frac{0.5000}{0.3000+0.5000} \times 0.1000=0.1375$.

In this study we measure an industry's position in the network using degree centrality, which is the sum of weights of an industry's edges divided by total number of industries (let it be $\mathrm{m}$ ) in the network (Aoibda, et al., 2014, Newman, 2003):

$C_{i}=\frac{1}{m-1} \sum_{j \neq i} A_{i j}$

Based on this measure, an industry is more central if it has more connections and/or stronger connections with other industries.

We obtained research and development data from the United States Bureau of Labor Statistics (BLS). Data are available in table 1.2 of "the Intellectual Property Capital by Measure for Major Sectors and NIPA-level Industries" data available at http://www.bls.gov/mfp/mprdload.htm\#Capital Tables Similar to the multifactor productivity data, BLS provides information about each industry's expenditure on research and development activities in each year, relative to its expenditure in 2009. Again, we transformed the base year from 2009 to 1997.

The data obtained from BEA Input-Output, BLS Productivity, and BLS Research and Development were merged for our analysis. Although the three data sets are at the 3-digit NAICS level, mapping is largely but not completely one to one. Specifically, there are 66, 60, and 55 industries in the BEA Input-Output data set, the BLS productivity data set, and the BLS Research and Development data set respectively. The difference among the three data set is that the BEA Input-Output data decomposes the Retail Trade industry into four industries while the other two combine the four into one. On the other hand, the BLS Research and Development data does not include 5 of the 60 industries in the BLS Productivity data set. For example, the farming industry is not included in the BLS Research and Development data. Therefore we aggregate the Input-Output table to 60 industries and calculate centrality and partner productivity growth based on the 60-industry Input-Output table. We use the 60-industry network instead of a 55-industry network because it more accurately reflects the trading relationships of industries in the United States. We also ran a regression based on the 55-industry network and the results were very similar. Our final data set is a balanced panel data set covering 55 industries for 16 years as research and development data were not available for 5 out of the 60 industries. For a list of the 55 industries used in this research please see Appendix A.

The independent and dependent variables used in the models are summarized in Table 1. 
Table 1

Variables and Sample Summary Statistics for the independent and dependent variables used in the models are summarized in Table

\begin{tabular}{lllll}
\hline & Mean & StdDev & Min & Max \\
Productivity Growth & 1.1943 & 0.3289 & 0.4968 & 3.7657 \\
Partner Productivity Growth & 1.2037 & 0.1410 & 0.9389 & 2.1053 \\
R\&D & 1.6735 & 1.0250 & 0.2488 & 11.9843 \\
Centrality & 0.8350 & 0.3738 & 0.3124 & 2.3575 \\
Observations & 880 & & & \\
\hline
\end{tabular}

Source: Authors' calculations

The above table is the summary statistics for the dependent variable productivity growth and the independent variables, Partner Productivity Growth, Research and Development (R\&D), and Centrality.

Table 2

Correlation between the dependent and independent variables in the model.

\begin{tabular}{lllll}
\hline & \multicolumn{1}{c}{$\begin{array}{c}\text { Productivity } \\
\text { Growth }\end{array}$} & $\begin{array}{c}\text { Partner } \\
\text { Productivity } \\
\text { Growth }\end{array}$ & R\&D & Centrality \\
$\begin{array}{l}\text { Productivity Growth } \\
\begin{array}{l}\text { Partner Productivity } \\
\text { Growth }\end{array}\end{array}$ & $0.4765^{*}$ & 1 & & \\
R\&D & $0.2094^{*}$ & $0.2817^{*}$ & 1 & \\
Centrality & $0.0650^{*}$ & -0.0515 & $-0.1390^{*}$ & 1 \\
\hline
\end{tabular}

Source: Authors' calculations

\section{Results and Discussion}

In our regression, we use the following panel data model on our balanced dataset with 55 industries over 15 years from 1998 to 2012. Though our original dataset starts with year 1997, our regression starts with year 1998 due to the use of lagged explanatory variables in the regression; data in 1997 are used to calculate lagged variables for the regression in 1998:

$Y_{i t}=F_{i}+\beta_{1} Z_{i, t-1}+\beta_{2} C_{i t}+\beta_{3} D_{i, t-1}+\beta_{4} D_{i, t-1} \cdot Z_{i, t-1}+\sum_{j=1}^{15} \rho_{j} r_{j}+\varepsilon_{i t}$

In equation (5) above, $Y_{i t}$ is the productivity growth of focal industry $i$ in year $t . F_{i}$ represents the time-invariant individual effects for industry $i . Z_{i, t-1}$ represents the productivity growth of industry i's partner industries in year $t-1$. $C_{i t}$ is industry i's centrality in year t. $D_{i, t-1}$ is the natural logarithm of industry i's research and development (R\&D) expenditure in year $t-1$. Here we use lagged partner productivity growth and lagged R\&D expenditure because we believe that it takes time for the productivity growth of partner industries to affect the focal industry. In other words, we believe that the impact of an industry's productivity growth is transferred through the network and reaches its neighboring industries after a time lag. Similarly, a focal industry's R\&D expenditure may not take effect immediately.

We perform a regression without any time lags and obtained very similar results. $D_{i, t-1} \cdot Z_{i, t-1}$ is the interaction of R\&D and partner productivity growth. We include this interaction term to examine if an increase in research and development is associated with more benefits from partner industries' productivity growth. $r_{j}$ 
$(j=1, \ldots, 14)$ is the dummy variable for year $j$ to capture the year fixed effects. $\varepsilon_{i t}$ is the error term.

We perform the Durbin-Wu-Hausman test to determine if we should treat our model as a random effects model or a fixed effects model. The test rejects the null hypothesis that the individual effect $F_{i}$ is uncorrelated to the independent variables. Therefore, we ran the model as a fixed effects model. The regression results are shown in Table 3.

Table 3

Regression Results

\begin{tabular}{lc}
\hline Independent Variables & Estimates \\
Partner Productivity Growth $\left(\beta_{1}\right)$ & $0.885^{* * *}$ \\
& $(6.22)$ \\
Centrality $\left(\beta_{2}\right)$ & $0.596^{* * *}$ \\
& $(6.01)$ \\
R\&D $\left(\beta_{3}\right)$ & $0.0806^{* * *}$ \\
R\&D x Partner Productivity Growth $\left(\beta_{4}\right)$ & $(3.12)$ \\
& -0.204 \\
Observations & $(-1.37)$ \\
\hline
\end{tabular}

Note: ${ }^{*} p<0.1,{ }^{* *} p<0.05,{ }^{* * *} p<0.01$

The above table shows the results of the regression analysis. Robust standard errors are shown in parentheses. Coefficients for the 14 year dummy variables are omitted. Source: Author's table.

Our study seek to answer two research questions. Whether a focal industry's productivity growth is influenced by (1) its partner industry's productivity growth and (2) its position in the network. The estimates of $\beta_{1}$ and $\beta_{2}$ provides answers to the two research questions.

Since $\beta_{1}$ is positive and significant $(P$ value $<0.001)$, this indicates that a focal industry's productivity growth is positively associated with its partner industries' productivity growth. In other words, a focal industry benefits from its partner industries productivity growth. If an industry is connected to some other industries which see significant growth in their productivities, this industry's productivity tend also to grow faster.

Since $\beta_{2}$ is positive and significant ( $P$ value $<0.001$ ), this indicates that higher centrality industries are more likely to experience a higher growth rate in their productivities, compared with industries at the peripheral of the network. This is due to the fact that central industries has access to a richer knowledge pool from a larger number of partner industries, which results in higher productivity growth for these focal industries.

In summary, we find supportive evidences that (1) productivity growth is transferred through the network from industry to industry and (2) an industry's productivity growth is influenced by its position in the network as demonstrated by the strong positive correlation between an industry's productivity growth and its network centrality.

Since, $\beta_{3}$ is positive and significant ( $P$ value $=0.002$ ), this indicates that $R \& D$ expenditure has a significant positive impact on productivity growth.

However, the interaction of R\&D expenditure and partner industries' productivity growth, $\beta_{4}$ is negative and not significant at the $10 \%$ level. Therefore, our study did not provide evidence that industries with higher R\&D expenditure benefit more from 
their partner industries' productivity growth. One explanation could be that innovations and imitations tend to be substitutes (Jovanovic, MacDonald, 1994). Industries which take the role of innovator (e.g., with higher R\&D expenditures) may not find enough opportunity to imitate other industries, compared with industries that focus more on imitation and less on innovation.

\section{Conclusion}

In this study, we investigate how the productivity growth of a focal industry is affected by (1) its partner's industries productivity growth, and (2) the focal industry's centrality in the network.

Based on an analysis of a balanced panel dataset with 55 industries over 15 years, the results shows empirical evidence that an industry's productivity growth is positively associated with its partner industries productivity growth. In other words, productivity growth propagates across the industry network. The paper also finds a positive association between centrality and productivity growth. That is, industries in more central positions in the network tend to have higher productivity growth.

Our study contributes to the extant productivity literature as it investigates the productivity issue by looking at all industries and explicitly modeling the whole economy as a network of supplier and customer industries. We believe that this network approach will have a far-reaching pertinence for understanding the determinants of productivity growth and hence economic growth, as the study of economic growth over time requires an analysis of industries as a whole.

This study is not without limitations. Our focus on the industry level is partly due to the data availability issue. However, it is the individual firm that makes productivity decisions. Therefore, future studies of productivity at the firm level using the network approach is desirable. Furthermore, studies that control for other factors that influence productivity growth may be conducted as well as studies using other outcome measures other than productivity growth.

\section{References}

1. Ahern, K. R. (2012), "Bargaining Power and Industry Dependence in Mergers", Journal of Financial Economics, Vol. 103, No.3, pp. 530-550.

2. Ahern, K. R., Harford, J. (2014), "The Importance of Industry Links in Merger Waves", Journal of Finance, Vol. 69, No.2, pp. 527-576.

3. Ahuja, G. (2000), "Collaboration networks, structural holes, and innovation: a longitudinal study", Administrative Science Quarterly, Vol. 45, pp. 425-455.

4. Aoibda, D., Caskey, J., Ozel, N. B. (2014), "Inter-Industry Network Structure and the Cross-Predictability of Earnings and Stock Returns", Review of Accounting Studies, Vol. 19, No.3, pp. 1191-1224.

5. Cao, M., Zhang, Q. (2011), "Supply chain collaboration: Impact on collaborative advantage and firm performance", Journal of Operations Management, Vol. 29, No. 3, pp. 163-180.

6. Doraszelski, U., Jaumandreu, N. B. (2013), "R\&D and Productivity: Estimating Endogenous Productivity", Review of Economic Studies, Vol. 80, No.4, pp. 13381383.

7. Fung, M. K. (2005), "Are Knowledge Spillovers Driving the Convergence of Productivity among Firms", Economica, Vol. 72, No. 286, pp. 287-305.

8. Griffith, R., Redding, S., Reenen, J. V. (2000), "Mapping the Two Faces of R\&D: Productivity Growth in a Panel of OECD Industries", available at http://hdl.handle.net/10419/90826 (01 August 2015). 
9. Huergo, E., Jaumandreu, J. (2004), "Firms' age, process innovation and productivity growth", International Journal of Industrial Organization, Vol. 22, No. 4, pp. 541-559.

10. Jaffe, A. B. (1986), "Technological Opportunity and Spillovers of R \& D: Evidence from Firms' Patents, Profits, and Market Value", American Economic Review, Vol. 76, No. 5, pp. 984-1001.

11. Jaffe, A. B. (1988), "Demand and Supply Influences in R \& D Intensity and Productivity Growth", Review of Economics and Statistics, Vol. 70, No.3, pp. 431437.

12. Jovanovic, B., MacDonald, G. M. (1994), "Competitive Diffusion", Journal of Political Economy, Vol. 102, No.1, pp. 24-52.

13. Newman, M. E. J. (2003), "The Structure and Function of Complex Networks", SIAM Review, Vol. 45, No.2, pp. 167-256.

14. Powell, W., Koput, K., Smith-Doerr, L. (1996), "Inter-organizational Collaboration and the Locus of Innovation: Networks of Learning in Biotechnology",

Administrative Science Quarterly, Vol. 41, pp. 116-145.

15. Rai, A., Patnayakuni, R., Seth, N., (2006), "Firm Performance Impacts of Digitally Enabled Supply Chain Integration Capabilities", MIS Quarterly, Vol. 30, No. 2, pp. 225-246.

16. Tsai, W. (2001), "Knowledge Transfer in Intra-organizational Networks: Effects of Network Position and Absorptive Capacity on Business Unit Innovation and Performance", Academy of Management Journal, Vol. 44, No. 5, pp. 996-1004.

17. Wakelin, K. (2001), "Productivity growth and R\&D expenditure in UK manufacturing firms." Research Policy, Vol. 30, No. 7, pp. 1079-1090.

18. Zailani, S., Rajagopal, P. (2005), "Supply chain integration and performance: US versus East Asian companies", Supply Chain Management, Vol. 10, No. 5, pp. 340348.

\section{About the authors}

Joe Teng is the Assistant Dean of International Engagement for the Sorrell College of Business. He teaches primarily in the information Systems discipline. He can be reached at Troy University, 238B Bibb Graves Hall, Troy, AL 36082 or by email at jteng@troy.edu

Dazhong Wu is an Assistant Professor of Information Systems and Decision Sciences at Troy University. His research appears in journals such as Marketing Science, Journal of Management Information Systems, and Information Systems Research. He can be reached at Troy University, 231C Bibb Graves Hall, Troy, AL 36082 or by email at wud@troy.edu

Fran Smith is an Assistant Professor of Information Systems and Quantitative Methods at Troy University. She can be reached at Troy University, 231D Bibb Graves Hall, Troy, AL 36082 or by email at fesmith@troy.edu 


\section{Appendix A}

Table 1

Balanced panel data set of 55 industries used in the study

\begin{tabular}{|c|c|c|}
\hline \# & Industry Name & BEA Input-Output Code \\
\hline 1 & Farms & $111 C A$ \\
\hline 2 & Forestry, fishing, and related activities & $113 F F$ \\
\hline 3 & Oil and gas extraction & 211 \\
\hline 4 & Mining, except oil and gas & 212 \\
\hline 5 & Support activities for mining & 213 \\
\hline 6 & Utilities & 22 \\
\hline 7 & Construction & 23 \\
\hline 8 & Wood products & 321 \\
\hline 9 & Nonmetallic mineral products & 327 \\
\hline 10 & Primary metals & 331 \\
\hline 11 & Fabricated metal products & 332 \\
\hline 12 & Machinery & 333 \\
\hline 13 & Computer and electronic products & 334 \\
\hline 14 & $\begin{array}{l}\text { Electrical equipment, appliances, and } \\
\text { components }\end{array}$ & 335 \\
\hline 15 & Motor vehicles, bodies and trailers, and parts & $3361 \mathrm{MV}$ \\
\hline 16 & Furniture and related products & 337 \\
\hline 17 & Miscellaneous manufacturing & 339 \\
\hline 18 & Food and beverage and tobacco products & $311 \mathrm{FT}$ \\
\hline 19 & Textile mills and textile product mills & 313ТT \\
\hline 20 & Apparel and leather and allied products & $315 \mathrm{AL}$ \\
\hline 21 & Paper products & 322 \\
\hline 22 & Printing and related support activities & 323 \\
\hline 23 & Petroleum and coal products & 324 \\
\hline 24 & Chemical products & 325 \\
\hline 25 & Plastics and rubber products & 326 \\
\hline 26 & Wholesale trade & 42 \\
\hline 27 & Motor vehicle and parts dealers & 441 \\
\hline 28 & Air transportation & 481 \\
\hline 29 & Rail transportation & 482 \\
\hline 30 & Water transportation & 483 \\
\hline 31 & Truck transportation & 484 \\
\hline 32 & Transit and ground passenger transportation & 485 \\
\hline 33 & Pipeline transportation & 486 \\
\hline 34 & Other transportation and support activities & $4870 \mathrm{~S}$ \\
\hline 35 & Warehousing and storage & 493 \\
\hline 36 & $\begin{array}{l}\text { Publishing industries, except internet (includes } \\
\text { software) }\end{array}$ & 511 \\
\hline 37 & Motion picture and sound recording industries & 512 \\
\hline 38 & Broadcasting and telecommunications & 513 \\
\hline 39 & $\begin{array}{l}\text { Data processing, internet publishing, and other } \\
\text { information services }\end{array}$ & 514 \\
\hline 40 & $\begin{array}{l}\text { Federal Reserve banks, credit intermediation, } \\
\text { and related activities }\end{array}$ & $521 \mathrm{Cl}$ \\
\hline 41 & $\begin{array}{l}\text { Securities, commodity contracts, and } \\
\text { investments }\end{array}$ & 523 \\
\hline
\end{tabular}




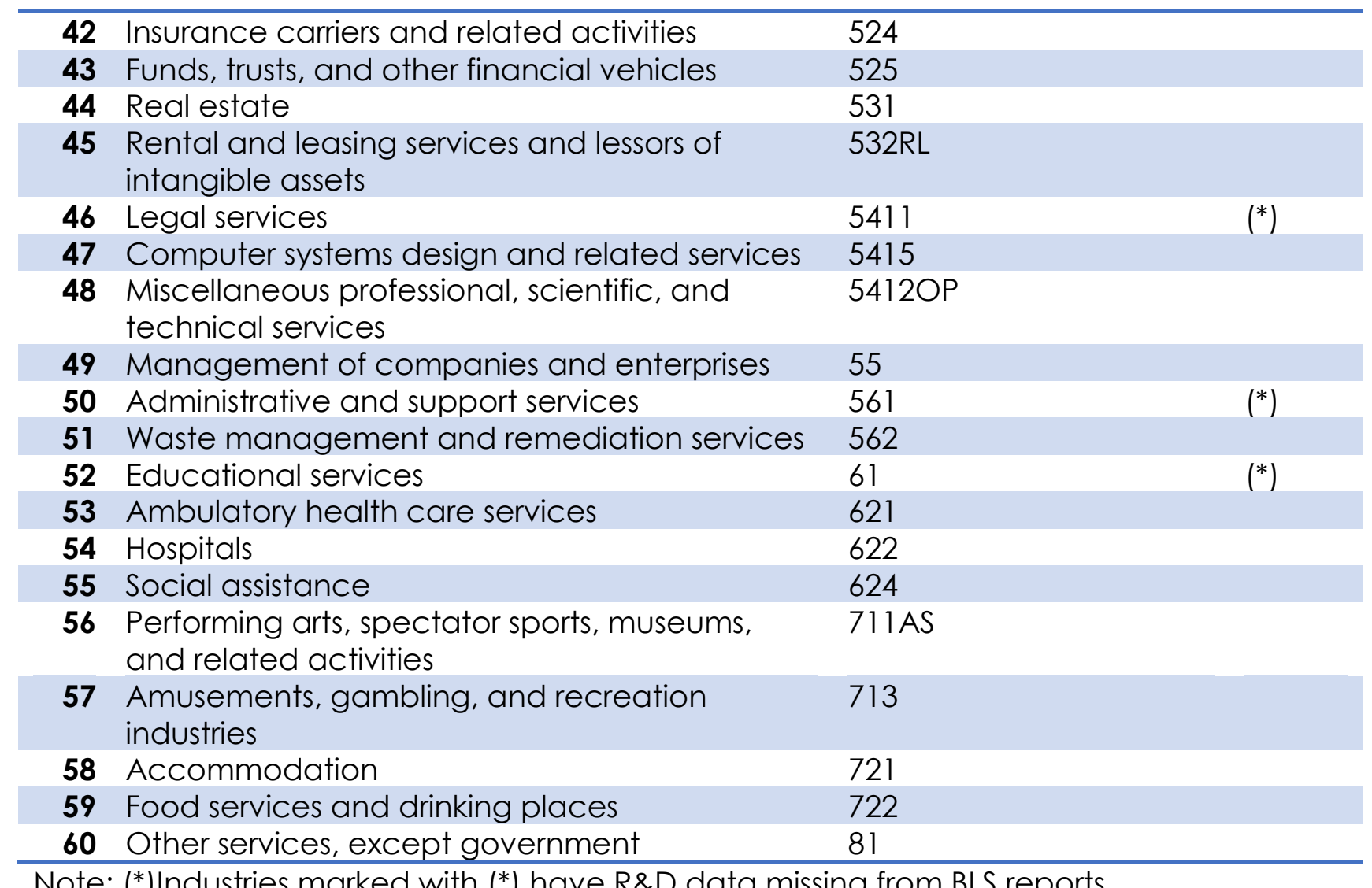

